\title{
東京と大阪の長期時間降水量データを用いた 降雨の時間分布特性の経年変化の検証 TREND ANALYSIS OF TEMPORAL DISTRIBUTION OF HOURLY PRECIPITATION BASED ON LONG TERM DATA AT TOKYO AND OSAKA
}

\author{
鈴木正人 $1 \cdot$ 鈴木航 2 ・杉原由基 3 \\ Masato SUZUKI, Wataru SUZUKI and Yoshiki SUGIHARA \\ 1正会員 工博＼cjkstart岐阜工業高等専門学校＼cjkstart環境都市工学科（二501-0495 岐阜県本巣市上真桑2236-2） \\ 2学生会員 岐阜工業高等専門学校専攻科 建設工学専攻学生（） 同上） \\ 3非会員 岐阜工業高等専門学校専攻科 建設工学専攻学生（） 同上）
}

\begin{abstract}
Recently, heavy hourly precipitation has been observed in Japan. It seems that intensification of heavy precipitation is related to urbanization, heat island phenomenon and global warming. But to clarify the change of hyetograph patterns, it is necessary to take a statistical test about time series of temporal and spatial distribution. In this paper, trend analysis of temporal distribution of hourly precipitation is carried out by Mann-Kendall test. The temporal concentration degree of precipitation is quantified by a gradient of ID (Intensity-Duration) curve. By applying to the hourly precipitation dataset form 1890 to 2012 at Tokyo and 1891 to 2012 at Osaka, it was showed that the temporal concentration degree is increased in August at Tokyo. Furthermore, it was proved that the long term data is useful for trend analysis of temporal distribution of precipitation.
\end{abstract}

Key Words : trend, hourly precipitation, long-term data, temporal distribution, ID analysis

\section{1.はじめに}

2013年の夏には多くの地点で大雨が観測された．1時 間雨量では山口（山口市，7月28日）で143mm，須佐 （萩市，7月28日）で138.5mm，鹿角（鹿角市，8月9日） で108.5mmなど多くの地点で観測史上1位を更新した. これら豪雨の原因を地球温暖化と結びつけて報道される ことも少なくないが，降水量そのものはもちろんのこと， 雨の降り方が経年的に変化してきているかを統計的に検 証することは，これからの河川計画を考えるうえで重要 な情報を与えることになると思われる.

温暖化に代表される気候変動が現在までの降雨にどの ような形で現れているか（または現れていないか），そ して，将来の降雨にどのような形で現れるかについて検 証する取り組みが気象分野，土木分野で行われている.

Fujibe et al. ${ }^{1}$ は日本の51地点の1901年から2004年という 長期の日降水量データを用い日降水量 $100 \mathrm{~mm}$ 以上の日数 の経年変化を求め，さらに2009年までデータ期間を延長
し再解析を行い ${ }^{2)}$ ，“日降水量 $100 \mathrm{~mm}$ 以上や200 $\mathrm{mm}$ 以上の 日数は年々の変動が大きく1940-1950年に極大，1980年 頃に極小を持つ長期変動を示しているが，全期間で通算 すれば100mm上の日数は21\%/100年の割合で増加する線 形トレンドが5\%有意で認められる”ことを示しているが， 時間的に集中した降雨の発生状況の経年変化を調べるた めには，時間降水量を検討対象にすることが望ましい.

アメダス観測值は日本全体に観測点が分布しており， データ期間長は30数年と長くは無いものの空間的に密な 資料を入手することができる。アメダス観測点 1000 点あ たりに換算した1975年から2012年までの1時間降水量 $50 \mathrm{~mm}$ 以上の発生回数の経年変化および $80 \mathrm{~mm}$ 以上の発 生回数の経年変化は，信頼度水準95\%（有意水準5\%) で増加の線形トレンドが認められる3)との報告がある. この報告では同時に，統計期間が短く変化傾向を確実に 捉えるには今後のデータの蓄積が必要なこと, 現時点で は増加傾向が地球温暖化の影響によるものかどうかは明 らかではないことも指摘している. Kanae et al. ${ }^{4}$ はアメダ 又観測值が得られる以前の東京の時間雨量データを気象 
庁に保管されているマイクロフィルムから入手寸ること で1890年から1999年までの年最大時間降水量および $50 \mathrm{~mm} / \mathrm{h}$ 以上の発生回数の経年変化を調べ，1940年代に 大きな時間降水量が発生し，その頻度も大きいことを示 している.この結果はアメダスに代表される1970年代以 降のデータのみを用いて経年変化を結論付けてしまうこ とは早計であることを示唆している。和田ら (5) $^{5} 1975$ 年 以前についてはKanae et al. ${ }^{4}$ と同じデータを用い, 最大時 間降水量のみでは表現できない, ひと雨のハイエトグラ フの形状の表現を意図し「ピーク雨量降り始めから ピーク雨量発生までの時間」の指標を導入し1890〜2008 年の経年変化を求めた。 これら時間降水量データを用い た長期の経年変化の検証の意義は大きいが，比較対象と して東京以外の観測点での適用が望まれる. 将来の降雨 がどのように変化するか，についてはGCM出力值を用 いた報告が数多くなされている. 降雨量のみではなく, 降雨の時空間分布特性の変化という視点から, 岡田ら ${ }^{6}$ はGCM出力を対象としたDAD解析を行いDAD関係が将 来に向けてどのように変化するのかを考察し, 将来の降 雨強度の増加, 従来のDAD関係を損なうような極端現 象の発生を示唆している.

降雨特性の経年変化を検証するためには長い期間の データを対象とし, 複数地点での比較が望ましいことは 先に述べたとおりだが，近年，気象庁により過去の降水 量データのチェックとディジタル化およびホームページ での公開が進められており?利用が可能になってきてい る. そこで本研究は，東京の1890年から2012年，大阪の 1891年から2012年のそれぞれ 120 年間以上の6,7,8,9月の 時間降水量データを用い，降雨の時間分布特性の経年変 化を検証したものである. 時間分布特性の表現は，ひと 雨を抽出しその時間的な集中の程度を定量化する方法と, 1年および10年単位で降雨の継続時間と降雨量との関係 であるDD式を求めそのパラメータにより表現する方法 を用いる. 経年変化については統計的有意性検定を行い 変化の有無を検証する.

\section{2. 対象データ}

\section{(1) 対象地点と期間}

気像庁ホームページで公開されているデータ8)を用い る. データ収集に取りかかった2012年10月の時点で長い 期間に渡るデータが収集可能な地点として東京地点（現 在の大手町）と大阪地点（現在の大手前）の2箇所を選 択した. データ期間は東京が1890〜2012年の123年間，

大阪が1891〜2012年の122年間である. 2012年10月の時 点で例えば名古屋地点は1916年以降のデータしか公開さ れておらず，しかも1961年から1975年までのデータが掲 載されていなかったので対象とはしなかった（本稿執筆 時の2013年9月に再度確認したところ名古屋は1891年以 降のデータが全て公開されている）。公開されている
データの内，梅雨，大気の不安定，台風を主な原因とす る降雨を念頭に置き全データ期間から6,7,8,9月の時間降 水量を入手した．欠測は東京が177時間で全360,144時間 $(=24$ 時間 $\times 122$ 日 $\times 123$ 年間 $)$ 中 $0.049 \%$, 大阪は久測が無 かった．東京の欠測については特に考慮をせず，降水量 が観測されなかったこととして扱う。なお，降水量には 降雨以外のものも含まれているが，対象としている6〜9 月は降水量は降雨量を表すと判断し，本稿においてはこ れ以降，降水と降雨を同じ意味で用いることとする.

\section{(2) データの継続性}

長い期間のデータを対象とする場合, データの性質の

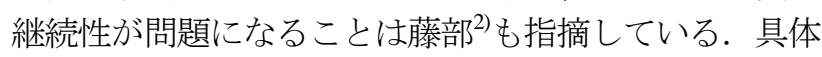
的には観測点の移動，および観測方法の変更が問題にな る.まず観測点の移動9)だが，東京は1890年以降1923年, 1964年の2回観測点が移動している．また，大阪は1891 年以降1910年, 1933年, 1968年の3回観測点が移動して いる.これら観測点の移動のうち最も移動距離が長かっ たのが大阪の1933年（西方向に9,184m）である. 移動距 離をどこまで許容するかの判断は難しいが，本研究では データ期間を長く取ることを優先し, 解析においては観 測点の移動は特に考慮せず, 降雨特性の経年変化を考察 する際に観測点の移動を念頭に置くに留める.

つぎに観測機器の変更について述べる.1960年代以前 は貯水型雨量計が用いられており測定単位 $0.1 \mathrm{~mm}$ でデー タが提供されている. 1960年代以降は転倒ます型雨量計 が用いられており, 測定単位 $0.5 \mathrm{~mm}$ でデータが提供され ている. 東京では1964年，大阪では1967年に観測機器が 変更された. 全期間を通し，精度未満（1960年代以前は $0.1 \mathrm{~mm}$ 未満， 1960 年代以降は $0.5 \mathrm{~mm}$ 未満）の降水が観測 された場合には「0.0」と表記されている．また，降水 が全く観測されなかった場合は「一」と表記されている. 全期間を一括して取り扱うためには，貯水型雨量計の測 定単位を転倒ます型雨量計の測定単位 $0.5 \mathrm{~mm}$ に換算する 必要がある. その方法として, 貯水型雨量計の測定值で $0.5 \mathrm{~mm}$ に満たないものは次の時間へと繰り越寸方法4,5が ある.この方法は, 転倒ます内に残っている $0.5 \mathrm{~mm}$ 未満 の降水は蒸発しないと仮定している。藤部 2 はこれとは 逆に，日付が変わると同時に転倒ます内の雨量は完全に 蒸発するという仮定で換算をし両者の比較・検討を行い, 強い降水に対しては両者の差は無視できることを示して いる. 本研究では既往の研究4),5)にならい貯水型雨量計の 測定值で $0.5 \mathrm{~mm}$ 未満は次の時間に繰り越寸方法を採用寸 るが無降水「一」と測定単位未満の降水「0.0」の区別 を考慮して換算する。.つまり, 貯水型雨量計で $0.5 \mathrm{~mm}$ 未満のものは次の時間に繰り越すが, 繰り越した際に $「$ 「」ではなく「0.0」に換算し「0.0」を降雨の継続時 間に含めることとする，換算例を表-1に示す．換算し た場合も両者の継続時間は一致することが分かる．これ らひと雨で繰り越すことのできなかった $0.1 \mathrm{~mm}$ は次回の 降雨時に加算寸る. 


\begin{tabular}{|c|c|c|c|}
\hline \multicolumn{4}{|c|}{ 表-1 測定単位0.1mmから0.5m搝算例 } \\
\hline 時刻 & 貯水型雨量 & 換算雨量 & 繰り越し \\
\hline 1 & - & - & 0 \\
\hline 2 & - & - & 0 \\
\hline 3 & 0.1 & 0.0 & 0.1 \\
\hline 4 & 0.3 & 0.0 & 0.4 \\
\hline 5 & 0.9 & 1.0 & 0.3 \\
\hline 6 & 3.4 & 3.5 & 0.2 \\
\hline 7 & 0.4 & 0.5 & $0.1 ※$ \\
\hline 8 & 0.0 & 0.0 & 0 \\
\hline 9 & - & $=$ & 0 \\
\hline 継続時間 & 6 & 6 & \\
\hline 総降水量 & 5.1 & 5.0 & \\
\hline & 回降 & 加算 & \\
\hline
\end{tabular}

\section{ID関係による降雨の時間的集中度の定量化}

ひと雨のハイエトグラフの時間分布特性に着目し，短 時間に雨が集中する程度，すなわち降雨の時間的集中度 を定量化し評価する. 和田ら ${ }^{51}$ はひと雨のピーク雨量 $\mathrm{P}$ と 継続時間Dの比であるP/Dおよび，ひと雨のなかでピー ク雨量に達するまでの時間をDとおいた新P/Dの指標を 用いてひと雨のハイエトグラフの形状を定量化している。 たとえピーク雨量が等しくても継続時間が短いほどP/D が大きくなり，ピーク雨量だけを指標として用いるより も的確に降雨の時間分布特性を表現できる。しかし， P/Dだけでは時間的な集中度を表現しきれない場合があ る. 図-1にピーク雨量すなわち最大時間降雨量, 継続時 間，総降雨量は等しいが形状が異なる2つの降雨の例を 示す．実際の観測值では無く，手法の説明のために模擬 的に作成したものである. 降雨(1)の方が降雨(2)に比べ て尖った形状になっている. 本研究では, このように, ピークがごく短時間に集中し，ハイエトグラフが尖った 形状の降雨特性を，時間的に集中していると表現する. 降雨(1)と(2)は最大時間降雨量と継続時間が共に等しいの でP/Dでは両者の差は表現できない.

降雨の時間的集中度をID解析の結果を利用して表現す る方法は松田ら ${ }^{10)}$ により提案されている. ID解析は，降 雨強度(Intensity) と時間(Duration)の関係を意味している。 本研究は, 松田 ${ }^{10)}$ にならい, $i$ : 降雨強度, $t$ : 継続時間の 関係として広く知られているSherman式 ${ }^{11)}$

$$
i=\frac{a}{t^{c}}
$$

で表される関係をあえてDD関係とは区別し，ID関係(また ID曲線)と呼び, ひと雨のハイエトグラフを対象に用いる.

また, Sherman式の両辺に継続時間 $t$ をかけて. 継続時間 $t$ における降雨量 $R$ と継続時間 $t$ の関係を表した次式をDD 関係(またはDD曲線)と呼び, ひと雨に限らず1年, 10年な ど一定期間の降雨を対象に各期間で観測された降雨量の 最大值を表現するのに用いる.

$$
i \cdot t=R=a \cdot t^{1-c}=a \cdot t^{n}
$$

(2)式は例えば宝ら ${ }^{12) ， 木 口 ら ~}{ }^{13)}$ が用いている。自明では

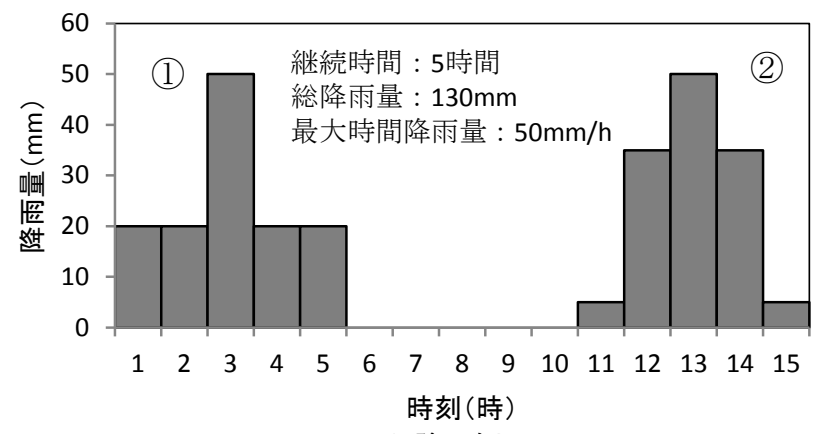

図-1 降雨例

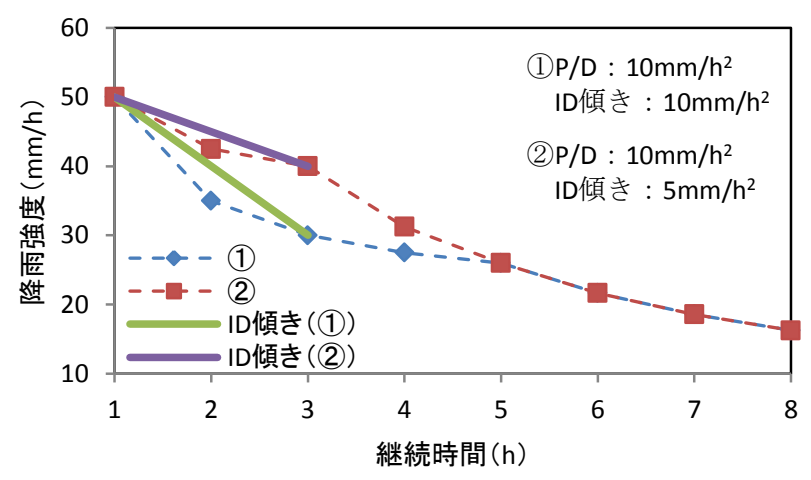

図-2 降雨例のID曲線

あるが，(1)式におけるiは坊大きくなるにつれて減少し， (2)式におけるRは㬵大きくなるにつれて増加する.

松田ら ${ }^{10)}$ は(1)式を両対数グラフ上にプロットしcを下 限時間 1 と上限時間 $T$ との 2 点から求めたものを $C$ と表現 し降水の時間集中度と定義している. C は降雨が単位時 間に集中する場合に $1, T$ 時間内に一様に分布する場合 に0となり降雨量には全く依存しない指標である.

本研究では，ID関係を図化したID曲線の傾きで降雨の 時間的集中の程度を表現する. 図-1に示した降雨(1)，(2) のID関係を図-2に示す. 降雨(1)の方がID曲線の傾きが急 になる．ID関係は一般には直線にはならないが，本研究 では継続時間1時間の降雨強度と継続時間3時間の降雨強 度の差を2時間（=3時間 - 1時間）で除したものを「ID 傾き」と定義し用いる. 表式化すれば次式となる.

$$
\mathrm{ID} \text { 傾き }=\left(I_{1}-I_{3}\right) / 2
$$

ここで, $I_{1}$ : 継続時時間1時間の最大降雨強度， $I_{3}$ : 継続時 間3時間の最大降雨強度，である. 図-2降雨(1)のID傾き は $10 \mathrm{~mm} / \mathrm{h}^{2}$, 降雨(2)のID傾きは5 mm/ $\mathrm{h}^{2}$ と降雨(1)のID傾 きの方が大きくなる．継続時間1時間と3時間の差とした のは，対流性降雨に代表されるせいぜい継続時間が数時 間の雨の時間分布の違いを表現することを意図し，やや 便宜的に決めたものであるが，時間差を幾つにしたら適 切かは検討の余地がある.

松田 ${ }^{10)}$ の定義している時間集中度 $C か ゙$ 降雨量に依存 しないのに対し，ID傾きは単位を持ち降雨量に依存する. 例えばハイエトグラフの継続時間を固定して降雨強度を 引き伸ばした場合には，引き伸ばし率に応じてID傾きも 大きくなる．また，例えば同じ降雨強度で3時間降り続 けば $I_{1}$ と $I_{3}$ が同じ值となりID傾きは0となる，一方，継続 時間が1時間の降雨の場合には， $I_{3}=I_{1} / 3$ となるので，(3) 
表-2 東京と大阪の降雨特性値

\begin{tabular}{|c|c|c|c|c|c|c|c|c|c|c|c|}
\hline & 月 & \multicolumn{2}{|c|}{6} & \multicolumn{2}{|c|}{7} & \multicolumn{2}{|c|}{8} & \multicolumn{2}{|c|}{9} & \multicolumn{2}{|c|}{$6 \sim 9$} \\
\hline & 項目 & 平均 & 最大 & 平均 & 最大 & 平均 & 最大 & 平均 & 最大 & 平均 & 最大 \\
\hline \multirow{6}{*}{$\begin{array}{l}\text { 東 } \\
\text { 京 }\end{array}$} & 対象とするひと雨の数 & \multicolumn{2}{|c|}{937} & \multicolumn{2}{|c|}{852} & \multicolumn{2}{|c|}{941} & \multicolumn{2}{|c|}{1075} & \multicolumn{2}{|c|}{3805} \\
\hline & 継続時間（h） & 16 & 81 & 12 & 73 & 9 & 78 & 14 & 83 & 13 & 83 \\
\hline & 総降雨量 $(\mathrm{mm})$ & 21.8 & 427.0 & 19.4 & 219.0 & 19.9 & 283.5 & 24.2 & 402.0 & 21.5 & 427.0 \\
\hline & 最大時間降雨量 $(\mathrm{mm} / \mathrm{h})$ & 5.8 & 38.0 & 6.7 & 88.5 & 8.0 & 69.5 & 7.0 & 68.5 & 6.9 & 88.5 \\
\hline & $\mathrm{P} / \mathrm{D} \quad\left(\mathrm{mm} / \mathrm{h}^{2}\right)$ & 0.7 & 19.0 & 1.0 & 29.5 & 1.4 & 16.3 & 0.9 & 18.2 & 1.0 & 29.5 \\
\hline & ID傾き $\left(\mathrm{mm} / \mathrm{h}^{2}\right)$ & 1.1 & 12.4 & 1.5 & 20.3 & 1.9 & 20.0 & 1.4 & 20.6 & 1.5 & 20.6 \\
\hline \multirow{6}{*}{$\begin{array}{l}\text { 大 } \\
\text { 阪 }\end{array}$} & 対象とするひと雨の数 & \multicolumn{2}{|c|}{1048} & \multicolumn{2}{|c|}{996} & \multicolumn{2}{|c|}{770} & \multicolumn{2}{|c|}{1032} & \multicolumn{2}{|c|}{3846} \\
\hline & 継続時間（h） & 14 & 66 & 10 & 82 & 7 & 54 & 11 & 75 & 11 & 82 \\
\hline & 総降雨量 $(\mathrm{mm})$ & 22.4 & 292.5 & 19.2 & 293.0 & 15.8 & 195.5 & 19.7 & 220.5 & 19.5 & 293.0 \\
\hline & 最大時間降雨量 $(\mathrm{mm} / \mathrm{h})$ & 6.7 & 50.5 & 7.5 & 59.5 & 7.6 & 73.0 & 7.1 & 64.5 & 7.2 & 73.0 \\
\hline & $\mathrm{P} / \mathrm{D}\left(\mathrm{mm} / \mathrm{h}^{2}\right)$ & 0.8 & 14.0 & 1.3 & 29.8 & 1.9 & 52.5 & 1.2 & 22.5 & 1.2 & 52.5 \\
\hline & ID傾き $\left(\mathrm{mm} / \mathrm{h}^{2}\right)$ & 1.4 & 12.5 & 1.8 & 18.9 & 1.9 & 22.1 & 1.6 & 14.9 & 1.7 & 22.1 \\
\hline
\end{tabular}

式より ID傾き $=I_{1} / 3$ となり, 少なくとも $I_{1}$, すなおちハイ エトグラフ中の最大 1 時間降水量はID傾きの3倍はあるこ とになる．すなわち，ID傾きが小さくても降雨量が少な い事を意味しないが，ID傾きが大きければ，少なくとも ID傾きの3倍の降雨量が降っていることになる.

\section{4. 東京と大阪の降雨特性の比較と経年変化}

\section{(1) ひと雨の抽出}

2章で述べた方法で東京と大阪の $6,7,8,9$ 月の毎時降水 量を測定単位を $0.5 \mathrm{~mm}$ に統一したものを対象に，ひと雨 を抜き出した。ひと雨は「降水が観測され始めてから観 測されなくなるまで」と定義した。データ上では無降雨 「一」から0.0mm以上の降雨が観測され始め, 再び無降 雨「一」となるまでがひと雨となる. その結果, 東京で は6,420個，大阪では6,163個が抽出された。

また，これらの「ひと雨」には降水量が少ないものも 含まれている. 微弱な降雨をその他の降雨と一括して取 り扱うと, 降雨特性值の平均值や経年変化がこれら微弱 な降雨に引つ張られて強い雨の降雨特性が不明確になる と判断し, 閾值を設けて微弱な雨を対象から除外するこ とにした．閾值を幾つにしたらよいかについては客観的 な基準が無い. そこで，経年変化の検証の観点から閾值 を決定する．経年変化を検証する際に，対象データが非 毎年值だと欠損值としての扱いが必要になる．また，結 果の解釈においても欠損值があるものと無いものを等価 に扱うことはできない.つまり対象データは毎年值であ ることが望ましい. 東京と大阪の各年・各月における最 大時間降雨量を求めたところ，大阪の1922年8月および, 大阪の 2000 年 8 月におけるものが $1.5 \mathrm{~mm}$ であり最大時間 降雨量としては最小值であった。 閾值を $1.5 \mathrm{~mm}$ よりき く設定するとこれら2か月は全ての降雨が閾值未満とな り降雨イベントが存在せず非毎年值となってしまうこと より，閾值を $1.5 \mathrm{~mm}$ とする．東京では6,420個中2,615個 が，大阪は 6,163 個中 2,317 個の最大時間降雨量が $1.5 \mathrm{~mm}$ 未満であり，全降雨の $40 \%$ にもおよぶことがわかった. これ以降は最大時間降雨量が $1.5 \mathrm{~mm}$ 以上のひと雨のみを 対象とする.

\begin{tabular}{|c|c|c|c|c|c|}
\hline \multicolumn{6}{|c|}{ 表-3 降雨特性間の相関（東京） } \\
\hline & 継続時間 & 総降雨量 & $\begin{array}{c}\text { 最大時間 } \\
\text { 降雨量 }\end{array}$ & $\mathrm{P} / \mathrm{D}$ & ID傾き \\
\hline 継続時間 & 1.000 & & & & \\
\hline 総降雨量 & 0.663 & 1.000 & & & \\
\hline 最大時間降雨量 & 0.214 & 0.696 & 1.000 & & \\
\hline $\mathrm{P} / \mathrm{D}$ & -0.306 & 0.081 & 0.549 & 1.000 & \\
\hline ID傾き & 0.030 & 0.457 & 0.927 & 0.669 & 1.000 \\
\hline
\end{tabular}

\section{(2) 降雨特性値の月別・地域別比較}

東京および大阪における月別の降雨特性值の平均值と 最大值を表-2に示す．東京の結果より6月は継続時間が 長いという梅雨性降雨の特徵が表れている．8月は継続 時間が短く，最大時間降雨量，P/D，ID傾きがともに大 きく短い時間に集中して降る対流性降雨の特徵が表れて いる．9月は総降雨量が多くまとまった雨が降る台風性 降雨の特徵が表れている. 大阪の場合も東京と同様に, 6月の継続時間の長さ，8月の最大時間降雨量， P/D, ID 傾きの大きさが特徴づけられるが，総降雨量については 9月が最大だった東京に比べ，大阪は6月が最大となって いる. 降雨特性值の值そのものは東京と大阪で大きな違 いはみられない.

\section{(3) 降雨特性值間の相関関係}

東京の降雨 3,805 ケースの降雨特性值間の相関係数を 表-3に示す. P/DとID傾きとの相関係数は0.669と大きい がID傾きと最大時間降雨量との相関係数0.927ほどでは 無い.またP/Dと総降雨量は相関関係がみられないのに 対し，ID傾きと総降雨量はある程度の相関関係がみられ る. なお，月別にも降雨特性值間の相関係数を求めたが 月による差異はみられなかった。

\section{（4）降雨特性値の経年変化}

降雨特性值の経年変化にはMann-Kendall検定を用いる. Mann-Kendall検定は水文時系列の傾向解析にも適用 ${ }^{14), 15)}$ されており，データの期間が短いと傾向変動を検出でき ないとの指摘16)もあるが，線形トレンドを求め $t$ 検定を 行う手法に比べて，母集団に正規分布を仮定しなくても よく，外れた值の影響を受けにくい点を評価した.

東京のID傾きの8月の平均值の経年変化を図-3に示す. 検定の結果 $4.2 \%$ 有意で増加傾向が認められた, このよう な検定を(1)各ひと雨毎の特性值を年単位で平均した時系 


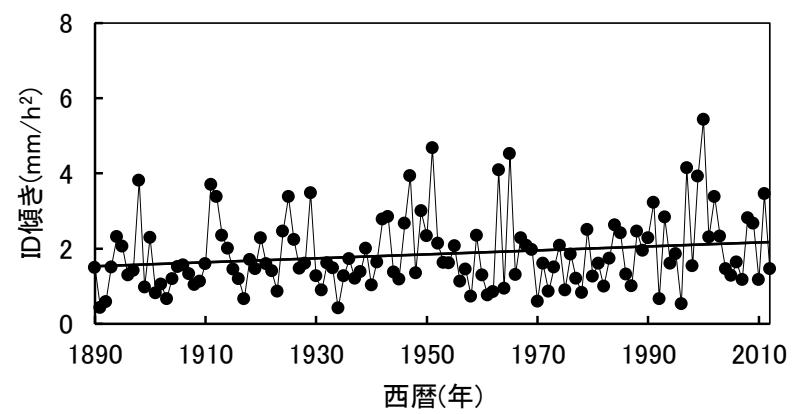

図-3ＩD傾きの経年変化（東京，8月，平均）

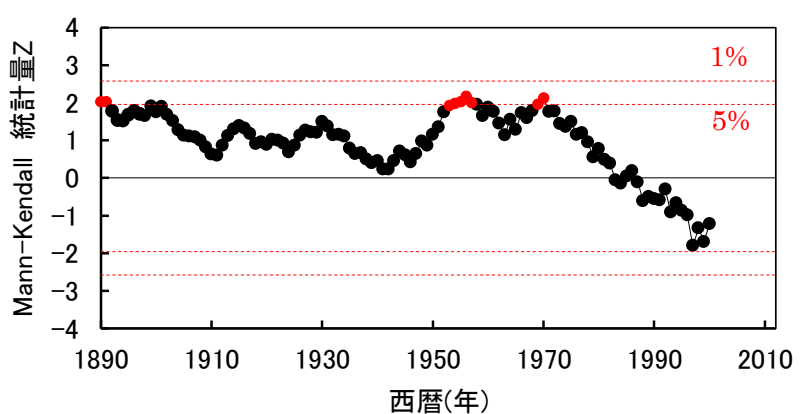

図-4 データ開始年とMann-Kendal有意確率

（東京, 8月, 平均)

列（表-4で「平均」と表現），(2)毎年最大時間降雨量を 含むひと雨の降雨特性值の時系列（表-4で「最大」と表 現）に対し行い有意確率をまとめた結果を表-4に示す. 表中でPは最大時間降雨量を表す。また，有意確率の前 の矢印は降雨特性值が増加傾向（入），減少傾向

（〉）のいずれかを表す．5\%有意が認められるのは， 東京8月のP/Dの平均およびID傾きの平均の増加傾向, 東 京の8月の最大の継続時間の減少傾向の 3 つのみであり 8 月の降雨が時間的に集中して降る傾向にあることを示唆 している. 東京の8月の最大時間降雨量の平均は増加傾 向であるが有意確率は $10.7 \%$ ありりその経年変化はP/D, ID傾きほどには明確ではない。この結果は，最大時間降 雨量そのものが増加傾向である可能性はあるが，それよ りも時間分布特性, すなわち雨の降り方の変化の方がよ り顕著であることを示唆している. 大阪は9月の継続時 間の平均, 最大時間降雨量の平均の有意確率が $5 \%$ に近 く増加傾向の可能性がある。 また，東京，大阪いずれも 「平均」の方が「最大」よりも有意確率が小さく経年変 化が明確であることより，経年変化は量の大きな強い雨 のみに表れている訳ではないことを示唆している.

\section{(5) 長い期間のデータを用いる意味}

本研究では120年間という長い期間の時間降水量デー タを用いてMann-Kendall検定によりトレンドの検定を 行ったが，地点によっては長期のデータが得られない場 合も考えられる. そこで，データ期間長を変化させて検 定を行うことで，長い期間のデータを用いる意味を確認 する. 図-3に示した東京8月のID傾き平均の時系列を元 にデータ期間の終わりを2012年に固定し，データ開始年 を1890〜2000年まで変化させた時系列データを作成する.
表-4 降雨特性の経年変化の増減と有意確率 $(\%)$

\begin{tabular}{|c|c|c|c|c|c|c|c|c|c|}
\hline & 月 & \multicolumn{2}{|r|}{6} & \multicolumn{2}{|c|}{7} & \multicolumn{2}{|c|}{8} & \\
\hline & 項目 & 平均 & 最大 & 平均 & 最大 & 平均 & 最大 & 平均 & 最大 \\
\hline \multirow{5}{*}{$\begin{array}{l}\text { 東 } \\
\text { 京 }\end{array}$} & 継続時間 & 759.2 & $\checkmark 33.5$ & $\nearrow 90.1$ & $\searrow 80.5$ & $\searrow 57.1$ & $\searrow 2.5$ & $\searrow 69.9$ & $\searrow 8.9$ \\
\hline & 総降雨量 & 786.3 & $\searrow 63.8$ & $\nearrow 41.2$ & 725.1 & 735.3 & 764.8 & 793.2 & 748.0 \\
\hline & $\mathrm{P}$ & $\nearrow 94.2$ & $\searrow 59.8$ & $\nearrow 18.6$ & 753.3 & $\nearrow 10.7$ & 765.4 & $\succ 9.9$ & 763.8 \\
\hline & $\mathrm{P} / \mathrm{D}$ & $\searrow 67.6$ & 764.5 & $\nearrow 27.0$ & 753.0 & $\nearrow 2.7$ & 77.82 & 751.6 & 723.9 \\
\hline & I傾き & $\searrow 78.5$ & $\triangle 92.2$ & $\nearrow 16.2$ & 751.6 & $\nearrow 4.2$ & 726.8 & $\nearrow 22.2$ & 767.6 \\
\hline \multirow{5}{*}{ 公 } & 継続時間 & $\nearrow 10.8$ & $\searrow 16.3$ & 73.9 & 752.5 & 782.7 & $\searrow 37.2$ & $\nearrow 5.4$ & $\nearrow 47.5$ \\
\hline & 総降雨量 & $\searrow 68.2$ & $\searrow 23.3$ & $\nearrow 29.7$ & $>9.3$ & $\searrow 62.8$ & $\searrow 24.4$ & $\searrow 97.4$ & 724.9 \\
\hline & $\mathrm{P}$ & $\searrow 57.6$ & $\searrow 20.6$ & 720.3 & $>61.2$ & $>20.0$ & $\searrow 99.5$ & 75.6 & 731.0 \\
\hline & $\mathrm{P} / \mathrm{D}$ & $\searrow 29.7$ & $\nearrow 63.7$ & $\searrow 12.2$ & $\searrow 59.7$ & $\nearrow 41.2$ & 788.6 & $\searrow 88.2$ & $\searrow 56.1$ \\
\hline & ID傾き & $\searrow 60$. & $\checkmark 72.8$ & 754.6 & $\triangle 72.5$ & 79.2 & $\nearrow 26.0$ & $\nearrow 10.0$ & 773.5 \\
\hline
\end{tabular}

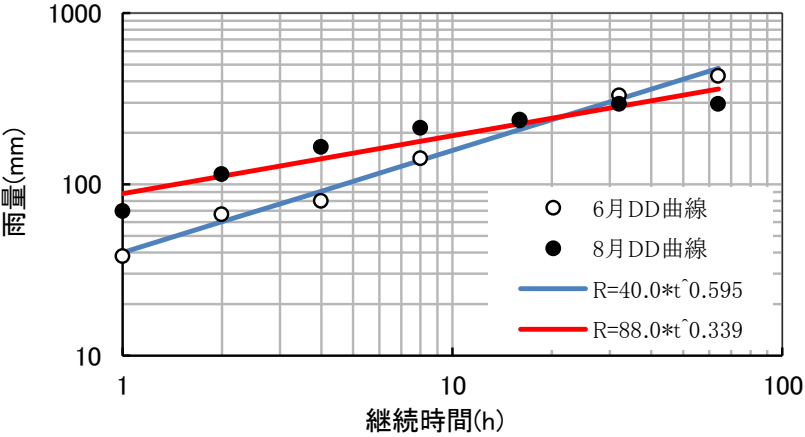

図-5 全期間を対象としたDD関係（東京）

各時系列データに対し，Mann-Kendall検定を行い得られ た統計量Zを図-4に示す。統計量Zの正負は時系列データ の増加傾向，減少傾向に対応し，Zの絶対值が2.58以上 の場合は経年変化が1\%有意，1.96以上の場合は5\%有意 であることを意味する.データ開始年を1980年以前にす るとZは全ての場合で正であり ID傾きの増加傾向を表し ている. データ開始年を1970,1971年，1955 1958年, 1890年，1891年とすると経年変化は5\%有意となる. 1970年付近,1955年付近を開始年とすると有意となるの は，これら開始年付近のID傾きの值が小さくなっている からである．逆にデータ開始年を1940年付近とした場合 にはZが小さくなっているがこれは1940年代後半から50 年付近にID傾きが大きい年が存在するためである.デー 夕期間長により有意確率は変化するので，利用できる限 り長期のデータを用いることが望ましい.

\section{DD関係の経年変化}

これまでは，ひと雨ごとのID関係を求めその経年変化 を検証してきたが，ひと雨に限らず，継続時間(Duration) と継続時間ごとの最大雨量(Depth)との関係，すなわち DD関係を求めてその経年変化を確認する.

まず，月別のDD関係を把握するため，東京の123年間 のデータを対象に，6月，8月のDD関係を図-5に示す. 1,2,4,8,16,32,64時間雨量の最大值をプロットしてある. またプロット点を(2)式で表したDD式も併記してある. (2)式の $a$ は1時間雨量の最大值に相当しnは継続時間が長 くなるに伴い雨量が増大する割合に相当する.このよう に $a$ と $n$ とで降雨特性が表現できる．8月は6月と比べて $a$ 
表-5 DD式パラメータの経年変化の増減と有意確率 $(\%)$

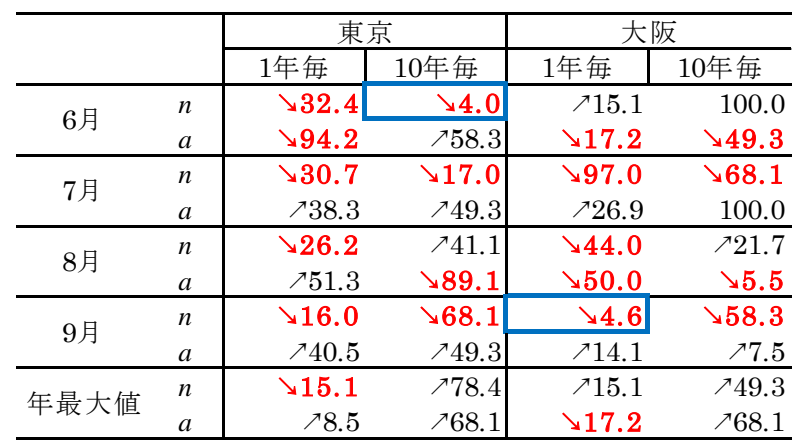

が大きく $n$ が小さい。これは8月が6月と比べて短い時間 の降雨量が多く，継続時間の長い雨量は少ないことを表 している.

つぎに，東京と大阪の6,7,8,9月のDD関係の経年変化 を検証する．各月ごとに1年単位および10年単位でDD関 係を定式化し(2)式の $a, n$ を求めた。毎年および毎10年 の $a, n$ を時系列とみなしMann-Kendall検定により経年変 化を検証した．表-4と同様に経年変化の増減とMannKendall検定の有意確率を表-5に示す，東京では1年単位 での経年変化において，すべての月でnは減少傾向であ りいずれの月においても雨の降り方が短い時間に集中す るようになってきている可能性はうかがえるが，統計的 に有意とは言えない. 大阪の場合は 1 年単位でみた場合 に9月の $n$ の減少傾向が5\%有意であり， $a$ の有意確率も $14.1 \%$ とその増加傾向をうかがわせる. これは表-3で示 した9月の最大時間降雨量の平均が $5.6 \%$ で増加傾向で あったことと対応する可能性がある.

\section{6. おわりに}

本研究では雨の降り方が変化してきているかを検証す ることを目的に，降雨が時間的に集中している程度を， ひと雨のハイエトグラフを対象にしたID関係の傾きで定 量化する手法を提案し，東京の123年間，大阪の122年間 の時間降水量データを対象に適用した．月別で比較した 結果，8月は他の月に比べてID傾きの平均值が大きく， 対流性降雨を原因とした降雨が多いという8月の降雨特 性を表現することが出来た。これら降雨特性值の経年変 化をMann-Kendall検定により検証した結果，東京の8月 は，最大時間降雨量そのものの経年変化は有意ではない ものの，最大時間降雨量継続時間，およびID関係の傾 きが5\%有意で増加傾向となり，東京の8月の降雨は時間 的に集中する傾向にあることが示された。 大阪の8月は ID関係の傾きは増加傾向ではあるが有意確率は9.2\%で東 京に比べると経年変化は明確ではないことが示された。 また，データ期間長を変化させてMann-Kendall検定を行 いその有意確率を求めることで，トレンドの検定に長期 データを用いることの意義を確認した.

さらに各年ごと，および10年間ごとにDD式を求めその パラメータの経年変化を検証した．東京の6月および大
阪の9月のパラメータの経年変化が5\%有意となった，こ の経年変化はいずれも継続時間の長い雨量の減少傾向を 意味するものであった。

今後, 適用地点を増やし地点間比較を進めていきたい.

\section{参考文献}

1) Fujibe, F. , Yamazaki, N. and Kobayashi, K. : Long-term cha nges of heavy precipitation and dry weather in Japan (1901-20 04) , Journal of the Meteorological Society of Japan, Vol.84, No. 6, pp.1033-1046, 2006

2)藤部文昭 : 日本の気候の長期変動と都市化-2010年度日本気象 学会賞受賞記念講演-,天気58.1,pp.5-16,2011

3)気象庁 : アメダスで見た短時間強雨発生回数の長期変化につ いて, http://www.jma.go.jp/jma/kishou/info/heavyraintrend.html, 2 013.9

4) Kanae, S. ,Oki, T. and Kashida, A.: Changes in Hourly Heav y Precipitation at Tokyo from 1890 to 1999, Journal of the M eteorological Society of Japan, Vol.82, No.1, pp.241-247, 2004

5)和田卓也・山田朋人 : 東京における 120 年時間降雨量データ を用いたひと雨降雨形態の日変化の検討, 土木学会水工学論 文集，第55巻，pp.481-486，2011

6)岡田翔太・鈴木善春・喜田智也：GCM出力に基づいた日本域 における降雨イベントの将来変化に関寸る研究，土木学会論 文集B1（水工学）Vol.69，No.4，I_373-I378，2013

7)戸川裕樹・渡邊進・阪田正明 : 東京と名古屋における過去の 毎時降水量データのディジタル化とそれに基づく強雨の経年 変化, 天気, 55.8, pp.27-29, 2008

8)気象庁 : 気象統計情報, http://www.jma.go.jp/jma/menu/report. html, 2013.9

9)気象庁 : 気象庁年報CD-ROM2005，気象業務支援センター

10)松田誠祐・足立真吾 : 降水の時間集中度に基づく結合確率 分布の実用性について, 自然災害科学 J.JSNDS, 24-3, pp.27 9-286, 2005

11)例えば，近森秀高・永井昭博・久保誉洋 : レーダー・アメ ダス解析雨量を利用したDAD 解析, 農業農村工学会全国大 会講演要旨集 pp.224-225, 2010

12)宝馨・端野典平・中尾忠彦 : DAD解析におけるレーダー雨 量と非線形最適化手法の適用, 土木学会論文集No.691/II-57,p p.1-11,2001

13)木口雅司・沖大幹 : 世界・日本における雨量極值記録，水 文・水資源学会誌, Vol.23, No.3, pp231-247, 2010

14)徐宗学・竹内邦良・石平博 : 日本の平均気温・降水量時系 列におけるジャンプ及びトレンドに関する研究，土木学会水 工学論文集, 第46巻, pp.121-126, 2002

15)小林健一郎・宝馨・中北英一 : 全球気候モデル出力を用い た日本域の 100 年確率日降水量の将来予測, 土木学会水工学 論文集，第54巻, pp.223-228, 2010

16)西岡昌秋・宝馨 : Mann-Kendall 検定による水文時系列の傾 向変動, 水文・水資源学会誌, Vol. 17, No. 4, pp. 343-353, 2004

(2013.9.30受付) 